returns to Paris and the establishment of a new order, the Discalced Carmelites, at the opening of the seventeenth century. One of the most interesting in the book, this case study explores how the Carmelite houses in Paris and Pontoise - the first to be founded in France-promoted alternative understandings of what constituted an ideal Carmelite community, casting light on how local circumstances shaped the creation of Catholic renewal foundations in new environments and the tensions that these differences could cause. The conclusion adroitly contextualizes the six case studies through comparison with other religious orders reinforcing and broadening the conclusion that there was no typical experience of Catholic renewal or reform even if some broad patterns emerge from the rich variety of local developments. The conclusion is worth special attention from readers as it sketches out many fruitful trails down that researchers should, and I hope will, venture in the future.

Those with a primary interest in the Jesuits might be frustrated by how little the Society features in this book. Still, some will find interesting the brief references to the adoption of Loyola's Spiritual Exercises by the Dominicans and the Trinitarians as they reformed the spiritual life of their foundations. Moreover, a careful reader will identify interesting parallels in the missions of the Jesuits and the Capuchins in Languedoc during the wars. Similarly, the factional splits within the Feuillants in Paris during the Holy League share many similarities to those experienced by the Jesuits. More generally, many will undoubtedly find inspiration in Diefendorf's local study approach, which offers intriguing possibilities for integrating the Jesuits into the nuanced and compelling story that she has sketched of the emergence of a "diverse, experimental, and experiential" Catholic renewal in France from the final decades of the sixteenth century.

\author{
Eric Nelson \\ Missouri State University \\ EricNelson@MissouriState.edu \\ DOI:10.1163/22141332-00603006-05
}

\title{
Jean-Pascal Gay
}

Le dernier théologien?: Théophile Raynaud (v. 1583-1663). Paris: Beauchesne, 2018. Pp. 488. $\mathrm{Pb}, € 41.00$.

Very very learned, indomitable, courageous, and incredibly energetic, the Lyonnais Jesuit, Raynaud (I shall henceforth refer to him as "R.") does not quite 
square with the ideal of theologian that Professor Gay searches for at the beginning of the book. Can the history of a theologian be written without emphasizing his teachings or his place on the rolls and "schools" of the discipline? What kept R. so engaged as a writer of theology, when he might have turned to history, devotional literature, or religious novels? Professor Gay admires R.'s tenacity and forgives him (rightly so) for his occasional laconic and bitter language; but after suggesting, as a heuristic device, that R. was the last theologian, a despairing negativism comes out rather too strongly in this reviewer's opinion. R.'s mission was to make readers think, to slow them down, to make them hesitate before adopting what might have been passed off as common sense.

R. perceived major changes in the Society of Jesus, the Compagnie to which he belonged. He combated politicization that led to public controversy; he warned of excessive devotional practices, especially as they were developing in newly founded female communities; he opposed censure that was petty and mechanical, he lamented the growing strength of the various national states that challenged or impinged on the Society of Jesus, and also on the Church Universal, and he attacked incursions by legal routines, including those grounded in canon law. He pondered over the transformation of the Society into an order whose raison d'être was now teaching: was this consistent with the original apostolic mission?

R. prompted readers to think about the relationship between pensionnaires and the order: about gifts (were strings attached?); about whether a rector could discharge a fellow Jesuit, and if so, on what grounds? What to do if someone flees? The answer depends in part on what he does in the future, for example join another community. Nor does R. find it desirable to have his confrères become the advisors and confessors to the women in the new orders. Was there an increased feminization of the church in this period? R. did not particularly seek lay readers who would come up to him and ask a question about grace. Needless to say, he strongly objected to women's reading and discussing theological issues. However, faced with several new readings of Augustine, R. did not mix practices and doctrine. He not only wrote a refutation of Descartes on the Eucharist, he also penned a refutation of the early Jansenist theologies.

His writing on the body (including uncorrupted bodies and saintliness) led him to favor cesarean surgery when it seemed necessary and he opposed castration for musical purposes. R. taught in the Roman College, so he became entirely familiar not only with Roman culture but also with the ways of the papal court. A decades-long quarrel over the censuring of his work in favor of a saintly status for those who had died of the plague in Lyon, 1627-28, led to a personal clash with Marino, the Dominican who headed the Index. Marino 
is characterized as ignorant of theology and arbitrary. An appeal to the pope to free him from the censure of his books seems not to have been successful. While such an appeal sounds arrogant, in fact it was not, because the Dominicans not only administered the institutions of censorship, but also their own writings did not have to be submitted for judgment. R. was strongly supportive of papal powers, but he did not become anti-Gallican.

There is so much more about R.'s career. His protectors included members of the houses of Savoy, Sforza, Barberini, and Sourdis (who was on the outs with Richelieu). The reception of R.'s writings, while considerable at the time of publication, withered quickly, leaving but an echo in Italy and, in France, some critical comments by Bayle, Niceron, and Baillet. The project to edit R.'s Opera omnia became a source of pride for members of his community and the devout of Lyon. Professor Gay often refers to R.'s autobiography, but does not really characterize it. Just how did he present himself?

The last big question is, of course: What was R.'s impact on the discipline of theology? While there were certainly reflections on the part of the initial readership, his works would be left on the shelves, not to be taken down again by a significant readership. Not one of R.'s works is listed among the great theological works of the seventeenth century. Professor Gay is to be commended for bringing him back to life, so that he can encourage readers to think hard about the relations between the theology of the church and the history of the church.

\author{
Orest Ranum \\ The Johns Hopkins University, Emeritus \\ orestranum@gmail.com \\ DOI:10.1163/22141332-00603006-06
}

\title{
Jaap Geraerts
}

Patrons of the Old Faith: The Catholic Nobility in Utrecht and Guelders, c.1580-1702. Catholic Christendom, 1300-1700. Leiden: Brill, 2019. Pp. xiv + 225. Hb, \$156.oo.

Historians have long understood that the English nobility and gentry helped Catholicism to survive as a minority within an Anglican state, causing the late John Bossy and, more recently, Brad Gregory to label early modern English Catholicism as quintessentially "seigneurial." Jaap Geraerts's monograph examines the corollary role of the Dutch Catholic nobility in the emerging republic, and assesses its impact on the resilience of Catholicism within this largely Reformed Protestant territory. In the Netherlands, as in England, official Catholic Church structures ceased to exist, authorities confiscated ecclesiastical 